\title{
SUPPORTING A STUTTERING STUDENT AT SCHOOL
}

\author{
Authors: \\ Tiiu Tammemäe $(\mathrm{PhD})$ \\ Tallinn University, Estonia \\ Sigrid Sõggel \\ Primary School Teacher at Rocca al Mare Kool, \\ Estonia \\ E-mail adresses: \\ tiiu.tammemae@tlu.ee \\ sigridsoggel@gmail.com
}

\author{
Lectors: \\ Magdolna Nemes(PhD) \\ University of Debrecen (Hungary) \\ Katalin Mező (PhD) \\ University of Debrecen (Hungary) \\ ... and other two anonym lectors
}

Tiiu Tammemäe, Sigrid Sõggel (2021). Supporting a Stuttering Student at School. Különleges Bánásmód, 7. (2). 91-104. DOI 10.18458/KB.2021.2.91

\begin{abstract}
Stuttering is a disability of tempo and rhythm in the speech that students, special education teachers, and speech therapists face in their daily work. Previously, stuttering has been researched from the perspective of speech therapy and speech therapists. This research is however based on the opinions of the youngsters in question. One percent of the population are considered stutterers as per Guitar's (1998) theory which would mean that in Estonia, approximately 1,500 students are stutterers. Students spend a large and valuable part of their day and leisure time at school. It is therefore essential that teachers and advisors are aware and competent in providing support to stuttering students as needed. These students do not receive enough support and attention, as stuttering is considered a disability that does not distract teachers from doing their job. It can be assumed that teachers do not change their methods and systems in evaluating a stuttering student. It is nevertheless crucial that the student with the impediment feels safe and good at school and can express their thoughts in speech. The aim of this research is to find out how stuttering students cope in their school environment. The research also focuses on the experiences of teachers and support specialists in order to understand their cooperation when assisting a stuttering student.
\end{abstract}

Keywords: stuttering, self-esteem, cooperation, school environment

Discipline: pedagogy

\section{Abstract: \\ DADOGÓ TANULÓ TÁMOGATÁSA AZ ISKOLÁBAN}

A dadogás a beszéd tempójának és ritmusának fogyatékossága, amellyel a gyógypedagógusok és a logopédusok a mindennapokban gyakran szembesülnek. A korábbi kutatásokban a dadogást a logopédia és a beszédterápiák szemszögéből vizsgálták, jelen kutatás azonban az érintett fiatalok véleményén alapul. 
Guitar (1998) szerint a lakosság egy százaléka dadogónak számít - ami azt jelenti, hogy Észtországban körülbelül 1500 tanuló dadog. A tanulók a napjuk és a szabadidejük jelentős és értékes részét az iskolában töltik, ezért elengedhetetlen, hogy a tanárok és a tanácsadók szükség esetén tudatosak és kompetensek legyenek a dadogó diákok támogatásában. A dadogó diákok nem kapnak kellő támogatást és figyelmet az iskolában, mivel a dadogás olyan fogyatékosság, amely nem zavarja a tanárokat a munkájukban. Feltételezhetô, hogy a tanárok nem változtatják meg módszereiket és értékelési rendszerüket egy dadogó diák esetében. Mindazonáltal kulcsfontosságú, hogy az akadályozott tanuló biztonságban és jól érezze magát az iskolában, és gondolatait beszédben tudja kifejezni. A kutatás célja annak kiderítése, hogy a dadogó diákok hogyan küzdenek meg iskolai környezetükben. A kutatás a tanárok és a támogató szakemberek tapasztalataira összpontosít annak érdekében, hogy megértsék együttmúködésüket a dadogó diákok segitésében.

Kulcsszavak: dadogás, önértékelés, együttmúködés, iskolai környezet

Diszciplína: pedagógia

Stuttering is defined by the International Disease Classifications (RHK10) as a disorder of behavior and emotional life that starts in childhood. The reasons behind stuttering have been studied for centuries and even today, researchers are unable to provide any certain theories for its cause. Stuttering is an impediment that occurs due to many different factors, the combination of which is very individual and unique to each person. It has been discovered that 95 percent of stutterers start suffering from the impediment between the ages of 3-7 and it is more common among children than it is among adults. Four percent or one out of 25 children ages 3-5 suffer from stuttering. It is in that same age range when physiological stuttering first emerges - the age-appropriate repetition of words that occurs in correlation with the development of vocabulary. For most people, stuttering stops before reaching adulthood. Boys are three to four times more likely to stutter than girls. There are many factors that can affect the progression of stuttering: the development of speech, environment, genetics, and sex, as well as the nature of the child (Kelman \& Nicholas, 2008; Onslow \& O Brian, 2013; Guitar, 2014). This is also confirmed by Ward (2006), who found that there are twice as many boys suffering from stuttering than girls in the preschool age range. Guitar (2014) has found that across all ages, there are approximately three male stutterers for every female stutterer. Although both girls and boys have the ability to overcome their stutter, women are four times as likely to improve in their symptoms than men (Ward 2006).

The progression of stuttering is characterized by four phases:

- The first phase or "primary stuttering" occurs from the ages of 2-5. Physiological stuttering may also occur, which can be characterized by mild repetition of full words, parts of phrases, and the first parts of words. These repetitions do not interfere with the normal flow of speech. Physiological stuttering is a normal part of oral development and it happens to about 25 percent of children. This kind of stuttering does not require any speech therapy and usually passes within two to six months.

- The age range for the second phase is very wide - some stutterers arrive by the age of 4 , while for others, it can happen in adulthood. 
Mainly this phase is reached in primary school. The child starts to sense that his speech does not meet expectations and therefore begins consciously seeking options to avoid mistakes. This however adds stress to speaking and can result in only making the impediment worse. Repetition, stretching, and strong blocking can occur and these factors will start to disturb the rhythm of speech.

- The third phase usually appears around the age of 8 , when the child becomes aware of his impediment. Due to incorrect speaking habits, the impediment gets worse as he struggles. There can be blocking, physical side effects, and bad breathing habits found in the speech. The child might develop fear, anger, and disappointment for situations that include communication and speaking.

- Secondary stuttering will develop during the fourth phase. A stutterer usually reaches this phase in his late teens or early 20s. The main keyword for this phase is fear of speaking and communicating that may be expressed in behavioral avoidance of these situations (Bloodstein, 1975; Jahu, 2008).

Based on the above, it is clear that by the age of 9-12, the child is likely to reach a phase in which stuttering will worsen due to a fear of speaking and behavioral avoidance of these situations. It is therefore important for children in that age group to receive speech therapy to prevent the complication of stuttering and to ease the secondary stuttering that is already there but not yet fully developed (Jahu, 2008). A speech therapist learns about stuttering from the person's behavior, speaking, interviews, and questionnaires. It can be used to research subjective evaluations of the communicative attitude and fears that come from situations of communication and use of words, as well as the overall effect of the impediment on everyday life.
The student's well-being as a beneficial factor for learning

Education is supposed to create meaningful social, cognitive, and academic opportunities for teachers and students alike. The school has a huge responsibility when it comes to the well-being of children. Attention from the teacher, social support of classmates, emotions from success, and the joy of friendships are of great support for a child to move forward (Cacciator et al, 2010). All previously mentioned objectives are associated with support for well-being. This support goes not only for academic achievements but also for a healthy development of personality. Healthy development is influenced by the overall atmosphere of the school and the class, support and care from teachers, as well as engagement with the school's values.

The school environment has an important impact on the student's behavior. Relationships with teachers and classmates are strongly related to psychological well-being and self-esteem. The mental health of a student can be influenced by stable relationships, motivation, sense of responsibility, and feeling safe in the school environment. If a student feels good at school, she will be motivated to actively take part in school life and will therefore have better psychological health as well as self-esteem (Sarkova et al 2014). From the perspective of contemporary learning, today's students have a more significant role and greater responsibility when it comes to managing their studies and acquiring knowledge in cooperation with teachers and classmates. The importance of active communication and teamwork with other students is more important than ever. Positive selfesteem is essential to successful learning.

A student spends a large part of her day in school and so the teacher's impact cannot be underestimated in regard to shaping the student's self-esteem. A safe atmosphere and confidence in succeeding are what motivates students to study, as 
well as excitement and clarity for specific tasks (Krull, 2018). A safe learning environment and a positive emotional atmosphere are important factors when it comes to successful studying. Even Maslow's (2017) Theory of Needs supports this studying is only possible when a student feels safe in class. In addition to providing a sense of dignity, emotional connection with the teacher can contribute to feeling safe. Stutterers feel a lot more stress than students who do not need to constantly prove their knowledge and skills as they speak smoothly (Crichton-Smith, 2002). According to research by Hayhow (2002), while at school, stutterers avoid reading aloud, answering the teacher's questions, or asking questions themselves.

\section{The shaping of a student's self-esteem}

Self-esteem is an individual's subjective evaluation of one's own worth, personal moral condition or belief in one's own mental abilities. The concept of good adaptation, self-acceptance and strength of ego (in the positive sense of the word) is often used. The Cambridge International Dictionary of English (2019) describes self-esteem as the belief and confidence in your own ability and value. The experience of communication that comes from family, friends, and school is of great importance in influencing self-esteem. It is developed by feedback from friends as well as experiences from the surrounding environment. Self-esteem plays a significant role when it comes to studying, acquiring knowledge, and delivering results. People with lower self-esteem tend to take fewer risks in social, academic, and work life. People with higher self-esteem also have a clearer and more stable vision of themselves, as well as greater expectations for their own achievements and targets.

The self-image of a student develops immensely during the school years and an influential role is played by children in the same age group
(Keltikangas-Järvinen, 2009). A child compares herself to others regularly in this phase of development and makes decisions about herself as a result. High self-esteem means that the person respects herself and finds herself worthy - not necessarily that she is better than others, but definitely not worse. She does not feel perfect, on the contrary - she knows her limits and hopes to grow and become a better person. Lower selfesteem means exclusion, dissatisfaction toward herself and self-contempt. The person has no respect for herself (Rosenberg, 1965). A feeling of constant failure may lead to lowered standards and self-esteem, which can result in dissatisfaction with school (Krull, 2018). The teacher plays a significant role in developing one's self-esteem. The emotional reactions that result from communication between students and teachers influence relationships and attitudes. As a result, either a supportive or a nonsupportive emotional learning environment is created.

An emotionally supportive learning environment can be characterized by mutual good relations between the student and the teacher, the feeling of belonging to the class, and motivation for studying (Evertson \& Weinstein, 2006; Wubbels et al, 2016). Positive relations with teachers will be more likely to occur if students feel safe at school beyond the classroom (Crosnoe, Johnson \& Elder, 2004). Wentzel (1992) recognized that emotionally supportive relations with the teacher can increase one's self-esteem and that the teacher plays a central role in coping with bullying and harassment in class.

\section{The environment's role in coping with stuttering}

Irrespective of a teacher's knowledge of speech therapy and stuttering in general, every teacher can create and encourage a positively successful experience in the classroom. The positive selfesteem of the stutterer needs to be encouraged and 
supported. Jahu (2005) presents some important topics that every teacher should think about. Most importantly, the teacher needs to be positive, supporting and encouraging both in attitude and expression. The teacher should help create a positive attitude toward the stutterer among classmates as well as the stutterer's parents. Jahu encourages teachers to create situations which help the class understand that it is unnecessary to always use speech in order to learn or answer. In addition, it is suggested for teachers to monitor their speed of speech and when possible, to make pauses in speech. In oral presentations, the student with the impediment should be included among the first to present and if necessary, also be allowed to present in writing instead.

When asking questions of the stuttering student, it is suggested to try to use wording for which the answer does not need to be long. When reading aloud, it is recommended to have students read in pairs, to altogether reduce the stress around oral presentation, and to encourage speaking. Presentations should be held in smaller groups and not in front of a large audience (Lees, 1999; Jahu, 2005). Davidow (2016) and fellow researchers point out different options and strategies that teachers could use in the classroom to support a student with this impediment. Patience is the keyword when it comes to listening. They encourage being active and responsive, but to avoid completing sentences or words for the student.

Teachers should also pay attention to body language and external signals by keeping eye contact and not dealing with any distractions. They further recommend letting the student know discreetly that the teacher is aware of the impediment and ready to support and help. Teachers ought to investigate which methods of answering and presenting the student prefers. More attention should be paid to the content of the speech, rather than the way it is presented.

\section{Methodology}

The aim of this research is to find out how a stuttering student is able to cope in a school environment. The research also focuses on the experiences of teachers and support specialists in order to understand their cooperation when assisting a stuttering student.

The research questions are as follows:

- What emotions does a stuttering student have in different situations of communication?

- What kind of adjustments have teachers made in their teaching to support a stuttering student?

- Which alternative ways and solutions based on ICT do teachers use to evaluate a stuttering student and to check their knowledge?

- How do teachers, speech therapists, special education teachers, and psychologists cooperate with each other to support a stuttering student?

In the article at hand, we focus on the first two research questions. The sample for the research was eight stuttering students ages 11-18. There were six subjects in the sample of teachers and support specialists (psychologists, speech therapists, special education teachers). For this research, we interviewed eight students aged 11-18 (marked as A, B, C, D, E, F, G, H). In addition, for the purpose of the study, two speech therapists (marked as L1, L2), two psychologists (marked as P1, P2), and two teachers (marked as T1 and T2) were researched.

To participate in the sample group, one of the following criteria had to be met:

- The interviewee is a stuttering child or youngster.

- The interviewee has experience in teaching a stuttering student in class.

- The interviewee has experience in counselling a stuttering student in therapy. 
The sample is composed of three parties: children with the impediment, teachers working at school, and speech therapists / psychologists. We did not find it important for the people in the sample to be related or part of the same network. The study was carried out using a qualitative method: a half-structured interview was held with each participant. On average, an interview with the students lasted for 49 minutes and it took 44 minutes on average with the adults. Written consent was provided by parents to conduct interviews with the students. All adults took part in the study as volunteers.

The aspects of validity and reliability show the accuracy and correctness of the construct that was created to collect data (Lodico, Spaulding, \& Voegtle, 2006). The validity of the research is ensured using the triangulation method, as the different methods of data collection help to prove the correctness of the data. The use of the triangulation method improves the validity of the study (Creswell, 2012). Also, the aspect of volunteering to take part of the study improves the validity of the sample of the research. The qualitative half-structured interviews that were used improve this research by providing more detailed answers and a richer overall picture.

\section{The Results of the Research}

Emotions of the stutterers in various communicational situations at school

When answering questions about their experiences, the interviewees were first asked to describe the emotions they feel in situations that require communication and speaking. Stuttering children and youngsters pointed out that communicational situations bring out fear, anxiety, discomfort, difficulty, and shame: A./.../ I usually feel good but when I start to stutter, then I kind of feel nervous.
The sensitivity that stuttering children and youngsters feel about their speaking is well described by two young male interviewees: F: /.../ I can't even get one word out of my mouth and then he looks at me weirdly. $\mathrm{H}:$ /.../ When I repeatedly stutter in front of the class, I feel like I'm wasting other people's precious time. This makes me feel like I have done something wrong, but actually I'm just trying to perform to get my grade.

Other interviewees also described the fear of what people or the class might think when they speak. H: /.../ I don't really raise my hand in class because all the others would need to wait after me for so long.

Specialists added insecurity to the emotions that have previously been listed. P: /.../ When the anxiety hits. Usually when there's more people around, they become more anxious. Or when there's a really important assignment.

Speaking in front of the class or to a complete stranger were the main situations brought out as difficult. G: /.../ Performing... in front of a large crowd... C: /.../ When there's a new person. I feel anxiety. For example, when in a job interview and I really try to leave a good impression.

Being at the center of attention was also acknowledged by the teachers and the same was confirmed by speech therapists and psychologists. S: /.../ It is natural for a child to feel anxious when they are at the center of attention, like when in front of the class: Will I perform well? What will happen today?

When the stuttering students were questioned about their experiences, they were first asked to describe the emotions that they feel in situations that require communication and speaking. The stutterers mentioned that situations of communication bring out fear, anxiety, discomfort, difficulty, and shame. A: /.../ I normally feel good, but when I start to stutter, I feel like, really nervous.

In addition, it was brought out that stuttering can cause disgust. E: / .../ Disgust... like others didn't really like when I started stuttering in front of the class.

During the interviews with stuttering students, it was discovered that they suffer from a much higher 
sensitivity about their speaking. The students mentioned that they are rather careful when it comes to situations of communication and they talk as little as possible. B: /.../ I usually don't talk that much. /.../ I am afraid that I might not be able to speak a certain word.

It was also mentioned that they are willing to avoid any communication as public performing is a big emotional challenge for the speaker. $\mathrm{H}: / . . . /$ don't really raise my hand in class because all the others would need to wait after me for so long. For some students, the tension and the anxiety before a situation of communication can be so great that it is hard to express themselves even verbally. F: /.../ I can't even say a single word.

The students feel mostly anxiety and fear when speaking publicly in front of others. A: /.../ I feel ashamed and like, I really don't feel good.

They are afraid of the reactions and attitude of their classmates. B: /.../Well, when I stutter, then I feel like someone might start langhing or something.

All the stutterers in this research were disturbed by the fact that they are not able to speak smoothly in every occasion or communication situation. Kids and youngsters admitted that they stutter the most when presenting in front of class. C: / .../When there's a presentation or something. I think that it happens most when I have to read something out loud, word-by-word, like from a textbook or something.

Also acknowledged was feeling insecure when they are not well-prepared or when they have doubts about their knowledge. F: / . . / when I don't know the subject too well. Like when I'm presenting in front of the class and I haven't prepared 100 percent. Like there are maybe some gaps in my knowledge.

Two of the interviewees admitted that it is hardest to talk to their parents as that is when the stuttering becomes the worst. A: /.../ It's really funny when I talk, to my mother - I really stutter. I don't know why!

It was also mentioned that sometimes when talking with family, it might be more difficult to talk to one parent than the other because of that parent's higher expectations for the child's speech and self-expression. H: /.../ This one time, I had to tell a story to my dad six times because be wanted me to speak properly and without stuttering.

The specialists found the biggest reason for stuttering to be anxiety and fear of speaking to strangers. P1: I think it's speaking with strangers. I think it might be when they need to compete for their turn to talk, /.../ when the child should perform his speech. The emotional tension grows.

In the speech therapist's opinion, it is most difficult to talk to the opposite sex and in a bigger group. L1: /.../ when talking to the opposite sex because there's this tension, the emotional tension. And the person might think about what kind of an impression he is making on the other people. He wants to leave a good impression. For the stutterer, the impediment really stands out - I mean everyone can hear it. I think that's when the tension really occurs. There are questions inside of the person like, 'am I good enough if I don't talk that much?' I think in a sense it's hard to speak. when there's friends and the pace of speech speeds up. Youngsters often speak really fast when in a group and interrupt each other.

When speaking of his feelings, a stutterer admitted that he avoids performing in front of the class even when he knows the subject really well. $\mathrm{D}: /$... I I say that I can't, or I just don't say anything when I'm in front of the class and the teacher asks something /.../ if I can't say it out loud, then I just say that I can't.

The researcher wanted to know what kind of help stutterers use to feel more secure and better in a communication situation. Most of the interviewees found that the most important and necessary help is collaboration with a speech therapist. E: /.../ we should turn to the ones who have studied the subject and know how to belp.

Multiple interviewees mentioned that they deal a lot with self-hypnosis and creating peace of mind. A: / ... / I just think 'calm down' and then exhale. Then I repeat this and peace of mind will come. 
For one interviewee, it helps to sing in order to overcome stuttering. B: / .../ My mother told me to sing. I have not thought about seeing a speech therapist. $\mathrm{H}$ : /.../ For preparation, I use the Alexander Technique and methods.

Two of the interviewees mentioned the importance of breathing. C: / ... / It's more like the breathing part is important for me.

Two of the interviewees also admitted that they have not used any help from therapists or psychologists to manage their impediment.

One of the interviewees described how important it is to create peace of mind. H: / .../ They could have a method or a memory that would belp them to remain calm. Calmness, I think, is one of the main things when it comes to communicating. For example, 'minutes of quietness' or meditation.

One of the interviewees would be open to options using psychotropic substances. F: / .../ more like to search for new solutions /.../, like there could be some lectures where they take a microdose of LSD or mushrooms and then you see inside yourself and start creating some connections. Like a different kind of therapy. I would be ready to try that kind of a thing, like it's an innovative solution but I do not want to seek help from a speech therapist.

According to the stuttering students themselves, they feel mostly comfortable and secure with their classmates. Two students and one psychologist described direct bullying and mocking from others. Both interviewees brought out that the classmates were mocking and laughing and the teacher allowed the class to react in that way. The psychologist also mentioned a situation in which the teacher could no longer be patient with a stuttering student and became very personal toward the impediment.

All the interviewees were asked to describe how they would imagine their life if they did not suffer from stuttering. The question noticeably enlivened all of the interviewees - their posture became more confident, their voice turned bolder, and they smiled. They were willing to describe their life as a non-stutterer with a louder voice and more confident body language. A: / .../ quite a lot. I really would like to not to stutter, ah well /.../.

The changes in everyday life were described as follows: B: / ... / it would change the way I read and talke and everything about my speech. /.../ I would be really happy and could speak nicely. I want it to disappear - I would really like to not to bave blockings in the beginning of a word or in the middle of $i$.

The stuttering students admitted that the impediment creates more tension and stress. D: / ... I I think like I wouldn't... worry anymore /.../ if I can do it or not.

In conclusion, it can be said that stutterers suffer from increased tension and anxiety in communication situations at school. There are children who would rather not raise their hand in class. Both the students and the specialists working with them found that the first assistance for a stutterer should come from cooperation with a speech therapist in order to learn different speech techniques. In addition, it was found that psychological help and the conscious control of one's thoughts will help to create peace of mind and reduce anxiety. A wide amplitude of techniques and therapies gives an idea of the severity of the stuttering impediment. The stutterers are willing to try different options in order to dispose of their impediment or to reduce its effect on their quality of life.

The adjustments made in the studying process to support a stuttering student

All the teachers, psychologists, and speech therapists who took part in the research found that stuttering is a special need that the teacher needs to take into account in class. T2: A stuttering cbild needs to be given more time to create a safe zone for them /.../ the teacher needs to take into account the peculiarities of the child in that environment as well as the reactions of other children. 
The teachers found that the child is not learning the subject if they do not take part of the conversation in class - even though the student is able to learn the subject, he is unable to express himself in the same way as other students. They also found that a stuttering student occasionally needs special attention in order to not make the situation any worse.

The teachers described the adjustments made in class as follows: T1: Well, it is definitely a special need, in the way that the evaluation of students really needs to be adjusted when it comes to verbal presentation in which the fluency of speech is an indicator of quality. / ... I can't assume that he reads a text fluently and then maybe the sentences are not stressed in the way that he wants, or how they should be.

The teachers found that it is necessary to give additional time to these students so they could adapt to the knowledge and prepare emotionally. T1: /.../ I understood that I shouldn't throw them in the water head first.

The teachers described how they sometimes signal to the students in advance about their upcoming verbal presentation. T2: / ... / I signaled to bim quietly, whispered to bim on my way past: Soon it will be your turn.

Both the teachers and the stuttering students admitted that in order to better understand each other, it is important to keep eye contact, checking facial expressions and body language in order to give stutterers a chance to step up when they are ready or when they wish. T2: / .../ I signal with my eyes if I want them to speak or not.

The teachers described how they go past the stuttering student and quietly slide their hand over the desk and whisper that they want the student to present soon.

The students were asked to describe how they present to the teachers in school - the results show the normality of the impediment. The students in the research were surprised and confused as most of them had no idea that the teachers could make any special adjustments for them compared with classmates. According to the students, they present in class on the same basis as everyone else. Only a few of the interviewees mentioned that occasionally they are given the opportunity to present individually or instead of verbal presentation to do it in writing instead.

All the subjects of the research found it important to get enough time to present. The stuttering students mentioned that they would feel better in school if they did not need to worry about the pressure of time. The teachers admitted that it is important to provide enough time to present, but also admitted that it is difficult for them to take it into account. T2: The most uncertain part is the silence thing. / ... / I still don't know how long of a pause can be considered normal and when exactly is it that the student is seeking some help.

The teachers also admitted that the pauses and waiting after a student can be annoying both for themselves and for the whole class.

Four of the interviewed stuttering students have had the chance to discuss their impediment with the teacher. All of the conversations were held on the initiative of the teacher. The stutterers mentioned that the teachers wanted to find out how the student would prefer to present and what else they - as teachers - could do in order for the student to feel better in class. These students felt more understood, and that their special need is something that is taken into consideration. F: Actually, everything is really good in school, the teachers know to take my condition into account.

Considering the stuttering students means that the teachers differentiate students when asking questions. F: / ... / They know what could be hard for me and they don't give it to me.

Although some of the students in the research didn't have a chance to discuss their impediment with the teachers, they all find it to be rather important. Most of the stuttering children were 
ready to have a conversation with their teachers and to discuss this subject.

Some of the stuttering students found the adjustments and special conditions to be unfair toward their classmates as well creating extra work for the teachers. $\mathrm{H}:$ /... / It would be annoying for the teachers to always think of other ways to present. B: The teachers should know the child and provide help to the extent that they can. There must be some limitations as everyone can't be taken as completely equal without making compromises.

The need for making adjustments and concessions was also confirmed by the specialists in the research. L1: /.../Well, it is definitely a special need in the way that the evaluation of students really needs to be adjusted when it comes to verbal presentation in which the fluency of speech is an indicator of quality. / ... I I can't assess his reading as fluent when the sentences are perbaps not stressed in a way that he wants, or how they should be. So, in verbal presentations, for sure.

It was also admitted that it is important to make adjustments for tasks and differentiate the students. The specialists emphasized the importance of adjusting the evaluation criterion for tasks in which verbal presenting is of importance for the speaker and therefore creates more tension and anxiety for the stutterer.

Both the stuttering students and the specialists agreed that the parents play a big role in informing the teachers and cooperating with them. They agreed that the parent should be the one who informs the teacher of the special need of their child. P2: / .../ The parent is actually responsible for telling the teacher about the impediment as well as any other special needs.

One of the teachers in this research had the experience of active and effective cooperation with a parent, making the teacher aware of the special need and competent in giving support. The second teacher however had no such experience and also no other colleague advised of the stuttering student in class. The teacher had to discover it herself and had to learn how to adjust herself to work with the stuttering student. The teachers would appreciate having information about their students in advance.

All the people in the research found that above all, awareness and attitude toward stuttering can be changed. The speech therapists and the psychologists mentioned that positive change begins with formative experiences in school. It is important to put more emphasis on humanity and relationships between students than on dutifully acquiring knowledge. P1: It would be a lot easier for a stuttering student if the relationships with classmates would be good and they are accepted as a bit different.

Both the speech therapists and the psychologists stressed that people should be valued in school in way that they don't get hurt. It is important to improve empathy. That is why the specialists recommend anti-bullying programs that create awareness for each side and the skills to value each other. The students think that it is important to talk about stuttering in school and that the teachers should help classmates to understand the stuttering student. E: And when the student starts to stutter, then others should not start langhing and they should accept him in the games and not exclude bim.

The people in the research found that the changes should also be made in the educational system and in the schools. All groups mentioned that class size could be smaller - this would make communication more natural and ease tension. In addition, one of the specialists found that the whole educational system should be changed as it no longer meets the needs of today's generation. T2: Smaller environments, smaller classes, smaller schools.

The specialists said that the teachers' workload is too high, which is why it is difficult for them to provide individual help and support for the students. P2: If the environment were smaller, then teachers would have more time to deal with that student.

A stuttering student described the problems that result from the fatigue of the teachers and 
overworking: F: / .../ I understand that the teachers get tired and they have their own job to do, but it's also their job to communicate with the students.

In conclusion, it can be said that all teachers, psychologists, and speech therapists in the research agreed that it is important to take into better account the peculiarities of the stuttering student. They found collectively that the parents, who know their child the best, should inform the teacher of the stuttering as it is a special need. Four of the students in the research have had the opportunity to discuss their impediment with the teacher and as a result, they feel more considered in class and that their verbal special need is taken into account in all seriousness. None of the specialists were of the opinion that evaluation terms need to be exactly the same for all students or that making individual adjustments would be improper.

As a final question, the researcher asked all of the interviewees what would be different in their lives if they did not suffer from stuttering. A: / .../ quite a lot. I really would like not to stutter... (voice breaks) ab well. B: / .../ it would change the way I read and talk and everything about my speech. /.../ I would be really bappy and could speak nicely. I want it to disappear - I would really like to not have blockings in the beginning of a word or in the middle of it. D: / ... I I think like, I wouldn't... worry anymore /.../ if I can do it or not.

\section{Discussion}

The aim of this research was to answer to the question: "What emotions does a stuttering student have in different situations of communication at school?" From the results of the research, it is evident that stuttering is a real problem for stuttering students and it limits them from feeling comfortable in situations of communication. Howell (2001), Jahu (2008), and Guitar (2014) have found that situations of speaking and communicating cause anxiety, fear, embarrassment, shame, and discomfort in stuttering students.
Chichton-Smith (2002) points out that stutterers feel a lot more stress when speaking than the students who do not need to constantly prove their knowledge and skills as they speak smoothly. Also, this research shows that speaking and presenting in front of a large auditorium is a big challenge for a stuttering child both emotionally and technically.

It turns out that stuttering students feel concerned about the opinions and comments from classmates. Mostly they are concerned about other people's impolite reactions and negative feedback. That is why the students admitted that they try to speak as little as possible in class. Some of the students have even considered getting around speaking by telling the teacher that they have not prepared for the lesson. This kind of behavior has also been described in research by Hayhow (2002) and Jahu (2008), who point out that stutterers may avoid reading out loud, answering questions, and asking questions. It takes a lot of courage and emotional work with oneself to overcome the fear of speaking.

From the results of the research, it appears that seeking assistance from a speech therapist might not always help stutterers in a way that they feel content with their verbal performance and are convinced as to the effects of the therapy. That is why some stutterers are ready to seek assistance through alternative options and different therapies. Stuttering students use conscious breathing, meditation, and different visualization and peaceof-mind exercises to better cope with situations of communication at school. The benefits of peaceof-mind exercises have been described by Boyle (2011) and the positive impact has also been confirmed in situational research conducted by Emge and Pellowski (2019).

According to Krull (2018), positive self-esteem and self-awareness as a learner can be enhanced if the student is guided to notice personal skills, performance, and achievements. It was a pleasure to note that all of the stutterers in this research had 
hobbies that made their eyes sparkle and offered emotional happiness.

The hobbies were introduced in a way that clearly showed that they are attended with great passion and commitment. It is probably the success in their hobby of choice that helps to compensate and relieve the negative emotions resulting from a lack of success in verbal presentation. Success in sports, dancing, music, learning foreign languages, and building academic knowledge can be of great help in increasing self-esteem and a feeling of capability.

The research was conducted to find out what kind of adjustments have been made by teachers in the studying process to support a stuttering student. Sarkova (2014) has found that the school environment has an important effect on the behavior and mental health of students. From the research, it appears that teachers find the wellbeing of a student important and are therefore willing to offer adjustments to stutterers accordingly. At the same time, the teachers admit that it is difficult for them to offer adjustments as they lack knowledge about the nature of stuttering and also of possible helping methods.

Surprisingly, it appears from the research that the majority of students who suffer from stuttering do not wish to be treated differently from their classmates. They find it to be unfair toward other students as well as adding to the workload of their teachers. This is most likely due to their being used to stuttering and the discomfort and difficulty that it causes. The stutterers themselves think that it is important to train communicational situations since speech is an important communicative instrument in everyday life. They find that public speaking and the courage to speak while stuttering in class would help to increase their self-esteem. At the same time, it appears from the research that stutterers worry about the opinion of their classmates. They are concerned about impolite reactions and negative feedback. It appears that stutterers would feel safer and less anxious if classmates and teachers would know and understand the peculiarities of their speech.

As a result of this research, it appears that the following adjustments have been used to help stuttering students in school: prior informing for speaking, individual presentation during or after class, written reporting, speaking outside of class with the teacher and also exemption from verbal presenting. Speech therapists pointed out that in addition to teaching speech techniques, they also prepare students for communicational situations through role plays. It appears from the research that stuttering students are concerned about the pressure of time when it comes to communicational situations in class. They are afraid that they are wasting too much valuable time of both the teacher and their classmates, since it takes longer to express themselves. The study shows that stutterers feel embarrassed when their partner or classmates need to wait for their turn to speak. Teachers are also concerned about the pressure of time - however for them, it is more about factors related to carrying out the class.

\section{Conclusion}

After analyzing the results, the following can be concluded:

- Stutters feel anxiety, fear, embarrassment, shame, and discomfort in communicational situations and are therefore reticent when it comes to speaking in front of the class; they prefer not to take the floor. In order to avoid public speaking, students may tell teachers that they are not prepared for class only because they do not want to present in front of the class or an audience.

- The majority of stutterers use help from speech therapists to acquire better speech techniques and skills to help themselves while speaking. If the goals they set for themselves are not achieved through therapy, they might 
lose hope for speech techniques and the effectiveness of help from speech therapists.

- Stuttering students would prefer to talk to their teachers about their impediment. For the stuttering student, it would serve as a sign that the teacher understands and cares about their issues and wishes to support their speaking in class.

- The teachers admit that they lack knowledge about the nature of stuttering and the support that can be provided for stuttering students in class. For this reason, they prefer not to discuss the subject. They rely on their best intentions and intuition when providing support, which is why their recommendations might not be in compliance with the scientific approach and that which is recommended by speech therapists.

- Speech therapists emphasize the importance of cooperation between teachers and therapists to ensure that the adjustments offered would actually benefit the stutterer and support their development. It is important to follow the principles of moderation and wisdom as stutterers need to have the opportunity to experience real communicational situations as well.

- Not every stuttering student wishes to be provided with special conditions when speaking, as they do not wish to be treated differently from their classmates. In addition, they find it unfair toward others and believe that providing special conditions will make extra work for the teacher.

The problem of the research was confirmed: a stuttering student lacks attention and support in the school environment. The assumption that stuttering is a special need that does not affect the usual way of carrying out a class was partially confirmed. Teachers are willing to help, adapt, and support a stuttering student in class, however it was found in this research that the issue is more a lack of knowledge than unwillingness to help.

\section{References}

Bloodstein, O. (2008). A bandbook of stuttering (6th ed). Clifton Park: Thomson Delmar Learning.

Bloodstein, O. (1975). A Handbook On Stuttering. San Diego: Singular Press.

Boyle, M.P. (2011). Mindfulness training in stuttering therapy: A tutorial for speech language pathologists. Journal of Fluency Disorders, $36.122-129$ doi: $\underline{\text { S0094730X11000386?via\%3Dub }}$

Cacciatore, R., Korteniemi-Poikela, E., \& Huovinen, M. (2010). Kuidas toetada laste ja noorte enesehinnangut. Tallinn: Varrak.

Chrichton-Smith. I. (2002). Communicating in the real world: accounts from people who stammer. Journal of Fluency Disorders, 27. 333-351. doi: $\underline{\text { S0094730X02001614 }}$

Creswell, J. W. (2012). Educational research: planning, conducting, and evaluating quantitative and qualitative research (4th ed). Boston (Mass): Pearson.

Crosnoe, R., Johnson, M. K., \& Elder, G. H. (2004). Intergenerational bonding in school: The behavioral and contextual correlates of students-teacher relationships. Sociology of Education, $\quad 77, \quad 60-81 . \quad$ doi: $\underline{10.1177 / 003804070407700103}$

Davidow, J. H., Zaroogian, L., \& Garcia-Barreta, M. A. (2016). Stuttering for Teachers to Manage Stuttering in the Classroom: A Call for Research. Language, Speech, and Hearing Services in Schools, 47. 283-296. doi: 10.1044/2016_LSHSS$\underline{15-0057}$

Cambridge International Dictionary of English (2019). https://dictionary.cambridge.org/dictionary/en glish/self-esteem

Emge, G., Pellowski, M.W. (2019). Incorporating a Mindfulness Meditation Exercise Into a Stuttering Treatment Program. Communication 
Disorders Quarterly, 40. 125-128. doi: $\underline{10.1177 / 1525740118783516}$

Evertson, C. M. \& Weinstein, C. S. (2006). Handbook of classroom management. Research, practice, and contemporary issues. Mahwah, New York: Larence Erlbaum Associates, In Guitar, B. (2014). Stuttering: an Integrated Approach to its Nature and Treatment. (4th ed). Baltimore, MD: Williams \& Wilkins.

Guitar, B. (1998). Stuttering: An integrated approach to its nature and treatment (2nd ed.). Baltimore, MD: Williams \& Wilkins.

Hayhow, R., Cray, A.M., \& Enderby, P. (2002). Stammering and therapy view of people who stammer. Journal of Fluency Disorders, 27, 1-17. doi: $10.1016 / \mathrm{s} 0094-730 \mathrm{x}(01) 00102-4$

Howell, P. (2011). Recovery from Stuttering. New York: Psychology Press.

Jahu, M. (2005). Kogelusest õpetajale. Haridus, 8, 15-17.

Jahu, M. (2008). Kogeluse modifitseerimisel põhinev kõneravi 9-12 aastaste lastega https://dspace.ut.ee/bitstream/handle/10062/ 5700/jahumaret.pdf?sequence $=1$ \&is Allowed $=\mathrm{y}$

Kelman, E., Nicholas, A (2008). Practical Intervention for Early Childhood Stammering. Palin PCI Approach.United Kingdom:Speechmark Publishing Ltd.

Keltikangas-Järvinen, L. (2009). Temperament ja kooliedu. Tallinn: Eesti Lastekaitseliit

Krull, E. (2018). Pedagoogilise psühboloogia käsiraamat. Tartu: Tartu Ülikooli Kirjastus

Lees, R. (2005). The assessment of children who stutter. In: Lees, R, R., Stark, C. (Ed), The treatment of stuttering in the young school-aged child (20-58). Chichester:Whurr.

Lodico, M. G., Spaulding, D. T., \& Voegtle, K. H. (2006). Methods in Educational Research: From
Theory to Practice. Ameerika Ühendriigid: JosseyBass.

Maslow, A.H. (2007). Motivatsioon ja isiksus. Tallinn: OÜ Mantra Kirjastus.

Onslow, M., O Brian, S. (2013). Management of childhood stuttering. Journal of Paediatrics and Child Health, 49,112-115. doi: 10.1111/jpc.12034. Epub 2012 Dec 18

RHK-10. /International Classification of Diseases/ https://www.kliinikum.ee/psyhhiaatriakliinik/li sad/ravi/RHK/RHK10-FR17.htm

Rosenberg, M. (1965). Society and the adolescent self-image. Princeton, NJ: Princeton University Press.

Sarkova, M., Bacikova-Sleskova, M., Madarasova Geckova, A., Katreniakova, Z., van den Heuvel, W., \& van Dijk, P. (2014). Adolescents psychological well-being and self- esteem in the context of relationships at school. Educational Research, 56, 367-378. doi: $\underline{10.1080 / 00131881.2014 .965556}$

Ward, D. (2006). Stuttering and Cluttering. Frameworks for understanding and treatment. New York: Psychology Press.

Wentzel, K. \& Miele, D. B. (2016). Handbook of motivation at school. New York, London: Routledge.

Wentzel, K. R. (1991). Social competence at school: Relations between social responsibility and academic achievement. Review of Educational Research, 61, 1-24. doi: 10.2307/1170665

Wubbels, T., Brekelmans, M., Mainhard, T., den Brok, P., \& van Tartwijk, J. (2016). Teacherstudent relationships and academic achievement. In K. Wentzel \& G. Ramani (Eds.) Handbook of Social Influences in School Contexts. Social-Emotional, Motivation, and Cognitive Outcomes (127-142). New York, NY: Routledge. 